\title{
Gastrokine 1 mRNA in human sera is not informative biomarker for gastric cancer
}

\author{
Valentina Villano ${ }^{1 \dagger}$, Chiara Stella Di Stadio ${ }^{1 \dagger}$, Antonella Federico ${ }^{1}$, Filomena Altieri ${ }^{1}$, Giuseppina Miselli ${ }^{1}$, \\ Maurizio De Palma ${ }^{2}$, Emilia Rippa ${ }^{1 *}$ and Paolo Arcari ${ }^{1,3^{*}}$ (D)
}

\begin{abstract}
Background: We aimed to ascertain if Gastrokine 1 mRNA in the sera of patients with gastric cancer might be an informative biomarker for the disease.

Results: Analysis of GKN1 mRNA in serum samples from healthy individuals $(n=23)$ and from patients with diagnosis of gastric cancer $(n=16)$, performed by using absolute quantification based on standard curve method, did not show any significative statistical difference between the two unpaired group of individuals.
\end{abstract}

Conclusions: Our preliminary results did not confirm GKN1 as a potential biomarker for gastric cancer.

Keywords: Absolute qRT-PCR, 18 kDa antrum mucosal protein, Gastric cancer biomarker, Gastrokine 1

\section{Background}

Gastric cancer (GC) is still one of the prevalent leading causes of cancer-related deaths worldwide and high mortality rate is mainly due to late-stage diagnosis [2]. Survival rate at 5 years of about $20 \%$ in most areas of the world $[6,11,32]$, except in Japan where mass screening programs, staging systems, and treatment may contribute to superior 5-year survival rates of approximately $60 \%$ [30, 35, 37]. In all Europe, the incidence is about 104,620 and 69,394 among males and females, respectively [16], representing about $23 \%$ of all cancers.

The most common type of stomach cancer is adenocarcinoma, which is divided into intestinal (well-differentiated) and diffuse (undifferentiated) each having different epidemiological and pathophysiological features [20]. The intestinal-type generally evolves through a relatively well-defined sequence of histological lesions, namely non-atrophic gastritis, chronic atrophic gastritis, intestinal metaplasia, and dysplasia $[4,5]$. On the contrary, the diffuse-type has instead a poorer prognosis and develops through unknown genetic and morphological events from normal gastric epithelium. The pathogenesis of $\mathrm{GC}$ remains poorly understood however

\footnotetext{
* Correspondence: emilia.rippa@unina.it; paolo.arcari@unina.it; arcari@unina.it ${ }^{\dagger}$ Equal contributors

${ }^{1}$ Department of Molecular Medicine and Medical Biotechnology, University of Naples Federico II, Via S. Pansini 5, I-8031 Naples, Italy

Full list of author information is available at the end of the article
}

several environmental factors, such as Helicobacter pylori (H. pylori) infection can be the cause leading to this disease. This risk is probably the result of a combination of genetic and environmental factors in which the infection by $H$. pylori is of particular relevance.

In a previous work, we analyzed the protein profile of malignant and normal gastric tissues and identified a novel stomach specific protein gastrokine 1 (GKN1) whose expression was reduced in $H$. pylori infected gastric mucosa and down-regulated or completely absent in GC tissues and precancerous lesions. [13, 28]. GKN1 belongs to a family of genes encoding stomach-specific proteins formed by 3 known members: GKN1 [23], GKN2 [9], and GKN3 [26]. These proteins, besides a highly conserved structure, show convergent functions in terms of modulation of gastric mucosal homeostasis and inflammation, activity in epithelial wound healing and/or repair, and antiproliferative activity. Moreover, they are highly expressed in the normal stomach and loss of GKNs expression in gastric cancers suggests putative tumor suppressor roles [24]. For instance, GKN2 knockout mice showed defective gastric epithelial differentiation whereas, loss of GKN2 in gp130 ${ }^{\mathrm{F} / \mathrm{F}}$ caused tumorigenesis of the proximal stomach. Furthermore, in H. pylori-infected GKN2 knockout mice, gastric immunopathology was accelerated and associated with augmented T helper cell type 1 (Th1) [25]. However, GKNs modes of action remain unsolved. Some findings indicated the involvement of GKN1 in the replenishment 
of the surface lumen epithelial cell layer, and in maintaining mucosal integrity [36]. After injury of the gastric mucosa, restoration may occur very rapidly in the presence of GKN1. In contrast, if the protein is down-regulated the repair process may be hampered [19]. Application of GKN1 to gastrointestinal cells promoted epithelial restoration and exerted its protective effect by increasing accumulation of specific tight and adherens junction proteins and also protecting their loss after injury [33].

Under this consideration, GKN1 might represent an important biomarker in carcinogenic process since it was seen that individuals with a lower expression of the protein have an increased risk to develop gastric diseases. We hypothesized that GKN1 mRNAs identified in serum of GC patients could become a completely non-invasive biomarker potentially distinguishing GC patients from healthy individuals.

\section{Results and discussion}

GKN1, also called Antrum Mucosal Protein of $18 \mathrm{kDa}$ (AMP-18) [40], is considered one of the most putative gastric cancer biomarkers [43]. Its low expression can be concluded in onset of malignancy. Moreover, while its presence in $H$. pylori negative patient is normal, it is decreased in H. pylori-positive patients [28]. Because human serum is a rich source of biochemical products that can act as indicators of the physiological or clinical status of a patient, we exploited the potentiality of GKN1 as gastric cancer biomarker trying to highlight its presence in human serum. We first used Western blotting technique to analyze human sera of healthy individuals. Because of the unusually high abundance of human serum albumin (HSA) in serum that can interfere with the resolution and sensitivity of several proteome techniques, samples were partially purified by Centricon 30 to remove high molecular weight proteins and then analyzed by Western blotting comparing the intensity of the signals with that of human gastric mucosal extract. Detection with monoclonal mouse anti-GKN1 antibody did not show any positive band signals compared to that shown by human gastric mucosal extract (from data not shown). This result was also confirmed by analyzing the same serum samples with ELISA kit for GKN1. Although its lower limit of detection $(0.056 \mathrm{ng} / \mathrm{mL})$, no absorbance was observed in all sera analyzed (from data not shown). Because the given detection limit of both GKN1 antibody and ELISA kit is about $0.15 \mathrm{ng} / \mathrm{mL}$ (using as control recombinant GST tagged GKN1), the lack of detection of GKN1 in human sera, unless it is totally absent, might probably depends by a far lower concentration of the protein. Therefore, more sensitive methods for the detection of the protein in the serum should be used in order to ascertain this possibility.
The above results prompted to search for GKN1 at transcription level. It is well known that mRNA in body fluid such as blood, has been proved as a novel resource to replace conventional tools for disease identification $[15,21,27]$, and successfully used as cancer-related biomarker [1, 31, 39]. In fact, mRNA markers have been the targets for identifying patients with colorectal, breast, lung, and thyroid cancers, and malignant melanoma $[3,12,17,18,40]$. All these published studies were performed for testing a single mRNA marker, however no much is known about the nature of circulating extracellular RNA (exRNA), including mRNA, and the possible mechanisms by which these RNAs are protected from plasma RNase activity [10]. One possible hypothesis is that exRNA present in plasma/serum are stabilized through binding to protein/lipoprotein complexes or that that are sequestered within lipid vesicles [14]. In this scheme, we tried to assess if GKN1 circulating mRNA in serum might represent a biomarker for gastric cancer detection. Therefore, we first tried to detect the presence of GKN1 mRNA in sera of healthy volunteers. Four sets of PCR primers (F1-R1, F2-R2, F3-R3 and F4$\mathrm{R} 4)$, covering GKN1 coding sequence at exon and intron bounda [32] of GKN1 gene, were defined by using PrimerBlast Server (Fig. 1) and used to perform semiquantitative PCR on fresh human sera. As reported in Fig. 2 (lanes a), all primer couples were able to amplify the corresponding GKN1 cDNA region giving PCR products of the expected length. This finding suggested the presence of a full GKN1 mRNA in the samples analyzed and the absence of possible PCR products deriving from genomic DNA. Because RNA is widely thought to be labile in the circulation, as reported by [38], we then analyzed the same blood samples that had been left at $4{ }^{\circ} \mathrm{C}$ for 24 h. As shown in Fig. 2 (lanes b), no difference was observed in the band intensities after repeating the PCR in the same conditions, thus confirming the general stability of mRNAs [38]. To check if the four PCR products were corresponding to GKN1 cDNA, PCR sequencing analyses were performed. The results confirmed that the nucleotide sequences of the four PCR products were encoding GKN1 (not shown).

Therefore, we decided to use the quantitative real-time PCR (qRT-PCR) strategy to detect GKN1 mRNA in the serum obtained from a population of wealthy subject and in that from patients with diagnosis of gastric cancer. We took advantage from a collection of sera withdrawn from patients with a diagnosis of gastric cancer that underwent surgical treatment. The clinicopathologic characteristics of the gastric cancer patients enrolled in this study are outlined in Table 1. The intestinal type was well differentiated in one, moderately differentiated in three and poorly differentiated in the remaining cases, while as far as concerns stage, these were all advanced. 
ataacacctagtttgagtcaacctggttaagtacaaatatgagaaggcttctcattcaggtccatgcttgcctact 5' UTR (105 Nts) $\stackrel{\text { Start }}{\longrightarrow}(+1)$

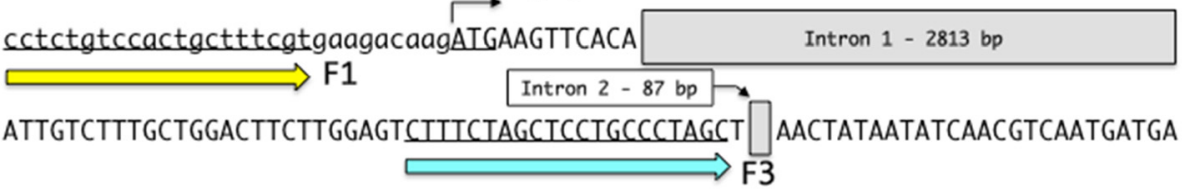

CAACAACAATGCTGGAAGTGGGCAGCAGTCAGTGAGTGTCAACAATGAACACAATGTGGCCAATGTTGACAATAAC $\longrightarrow \mathrm{F} 4$
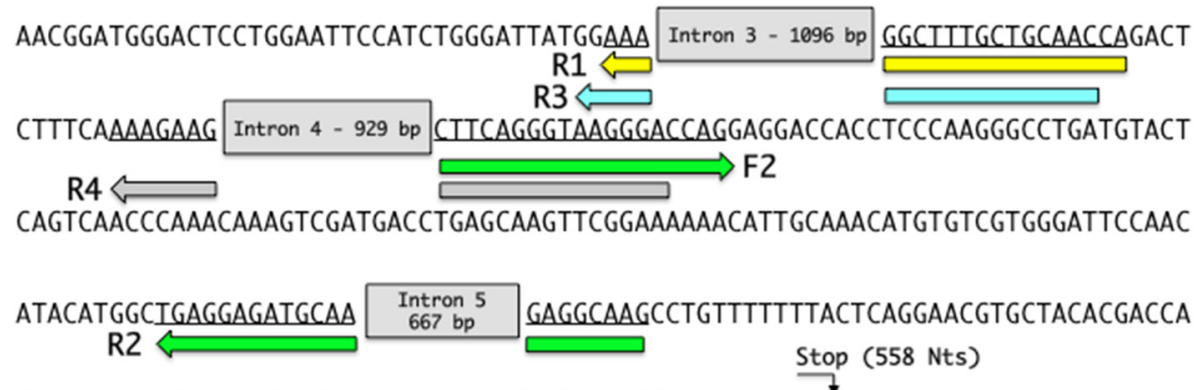

GTGTACTATGGATTGTGGACATTTCCTTCTGTGGAGACACGGTGGAGAACIAÄacaatttttaaagccactatgg

atttagtcatctgaatatgctgtgcagaaaaaatatgggctccagtggtttttaccatgtcattctgaaatttttc tctactagttatgtttgatttctttaagtttcaataaaatcatttagcattgaattcagtgt 3' UTR (161 Nts)

Fig. 1 Design of PCR primers for the detection of GKN1 mRNA in human sera. Structure of GKN1 gene and nucleotide sequence of GKN1 mRNA. The coding region is represented in capital letters, $5^{\prime}$ and $3^{\prime}$ UTR are in lower case, start and stop codons are underlined, intron regions are boxed. PCR primers pairs F1-R1, F2-R2, F3-R3 and F4-R4 are highlighted in yellow, green, azure and gray, respectively

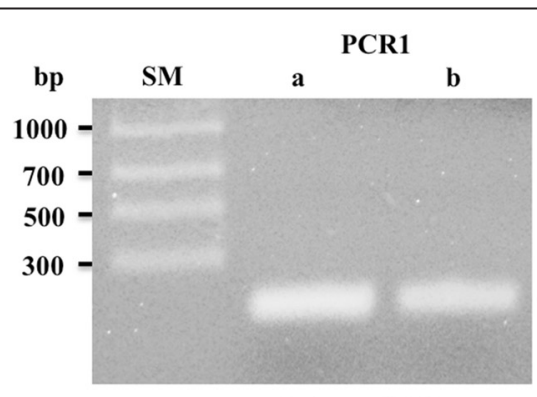

Primers F1-R1

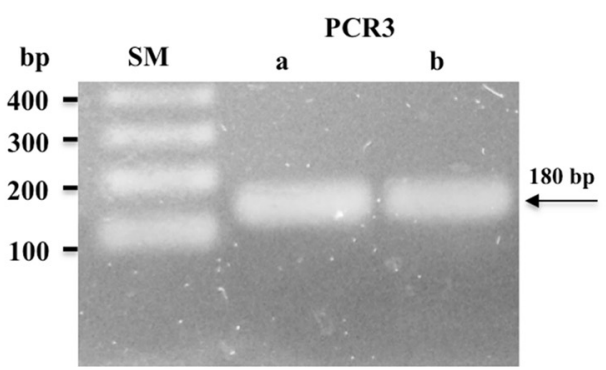

Primers F3-R3

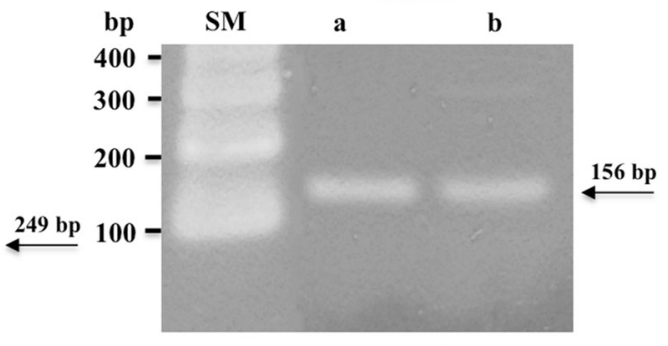

Primers F2-R2

PCR4

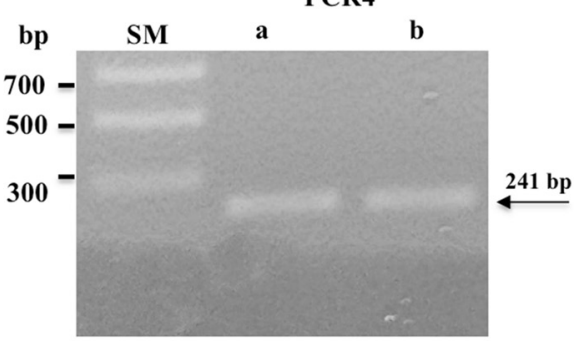

Primers F4-R4

Fig. 2 Semiquantitative PCR of GKN1 mRNA expression in human sera. Representative semiquantitative PCR performed on a serum of a healthy subject performed before (lanes a) and after (lanes b) storage of the sample at $4{ }^{\circ} \mathrm{C}$ for $24 \mathrm{~h}$. PCR reactions (PCR1, PCR2, PCR3 and PCR4) were carried out using the primers pairs F1-R1, F2-R2, F3-R3 and F4-R4 as reported in Fig. 1 
Table 1 Characteristics of Healthy Subjects and Gastric Cancer Patients

\begin{tabular}{lll}
\hline Variable & $\begin{array}{l}\text { Healthy }{ }^{a} \\
\text { Subjects }(n=23)\end{array}$ & $\begin{array}{l}\text { Gastric Cancer } \\
\text { Subjects }(n=16)\end{array}$ \\
\hline Age (years) & $59 \pm 25$ & $64 \pm 13$ \\
Sex ratio (M:F) 8:23 1:6a & $14 / 9$ & $9 / 7$ \\
Tumor type & - & Intestinal 9, Diffuse 7 \\
Grade of differentiation & - & Well 1, Moderate 3, Poor 12 \\
Stage & - & Early 0 (0 \%); \\
& & Advanced 16 (100\%) \\
\hline
\end{tabular}

${ }^{a}$ All healthy individuals included did not have dyspeptic symptoms

Diffuse type GC was poorly differentiated and advanced in all cases. The non-tumoral areas of intestinal type GC showed a variable degree of atrophy with diffuse IM, instead, the non-tumoral areas of diffuse type GC showed a variable degree of non-dysplastic inflammation. Characterization of non-tumoral gastric mucosa $(\mathrm{N})$ from tumoral $(\mathrm{T})$ one was based on the macroscopic aspect of the normal tissue compared to the tumoral one, as evaluated from the hospital pathologist. Moreover, paired specimens of non-tumoral $(\mathrm{N})$ and tumoral $(\mathrm{T})$ gastric mucosa where analyzed by Western blotting for GKN1 expression levels. As shown in Fig. 3, compared to non-tumoral tissues $(\mathrm{N})$, in the corresponding tumoral tissues $(\mathrm{T})$ it was observed almost a complete down-regulation of GKN1 at protein level [8]. To assess whether the GKN1 down-regulation occurred also at mRNA level, qRT-PCR analyses were performed on total RNA extracted from three paired non-tumoral and tumoral gastric tissues (Fig. 3c). GKN1 mRNA is one of the most abundant transcripts known in the normal stomach (about $1 \%$ of total gastric mRNA), often undetectable in gastric tumor tissues by Northern blotting [29]. However, qRT-PCR is a more sensitive method able to unveil the presence of low levels of a given mRNA in cells/tissues [7]. As shown in Fig. 3c, compared to nontumoral tissues, qRT-PCR showed a decrease of GKN1
mRNA level in tumoral tissues [42]. Therefore, based on these findings, our hypothesis was that compared to healthy subjects, in sera of patients with GC, lower significative levels of GKN1 mRNA could have been evaluated by quantitative analysis.

qRT-PCR was performed by absolute quantification by a standard curve method constructed using as reference DNA a plasmid containing flGKN1 cDNA [34] and as primers the F2-R2 pair ( Fig. 4). We used serial 10-fold dilutions of plasmids to construct a standard curve by plotting the logarithm of the plasmid copy number against the measured cycle values. The standard curve had a wide range of DNA copies/ $\mu$ l (from $3.78 \times 10^{1}$ up $\left.3.78 \times 10^{8}\right)$ with a linear correlation $\left(R^{2}\right)$ of 0.99351 , and a slope of -3.909 (Fig. 4a). The level of circulating GKN1 mRNA of all 23 healthy samples showed a median cycle number value of 29.6673 (range 27.70231.380). GC patients gave a median Ct value of 30.1269 (range 28.713-31.279). The statistical evaluation of the results using Student $t$-Test of unpaired data with unequal variance indicated a non-significant difference between the two groups $(p=0.1138)$. From the standard curve, the mean circulating copies of GKN1 mRNA were $1.81 \times 10^{5}$ and $2.38 \times 10^{5}$ copies $/ \mathrm{ml}$ in patients and healthy individuals, respectively (Fig. 4b). Despite the strong downregulation of GKN1 protein levels in gastric cancer, the quite comparable levels of GKN1 mRNA strongly indicated that this down-regulation is not observed at transcription levels thus suggesting translation regulation mechanism for GKN1 expression. The result obtained suggested to direct the search towards other non-invasive gastric cancer biomarker such as long noncoding RNAs (lncRNAs), a recently discovered class of noncoding RNAs (ncRNA) that are emerging as a promising new class of biomarkers for tumour diagnosis [41].

\section{Conclusion}

In conclusion, although we have shown for the first time the presence of GKN1 mRNA in human serum of

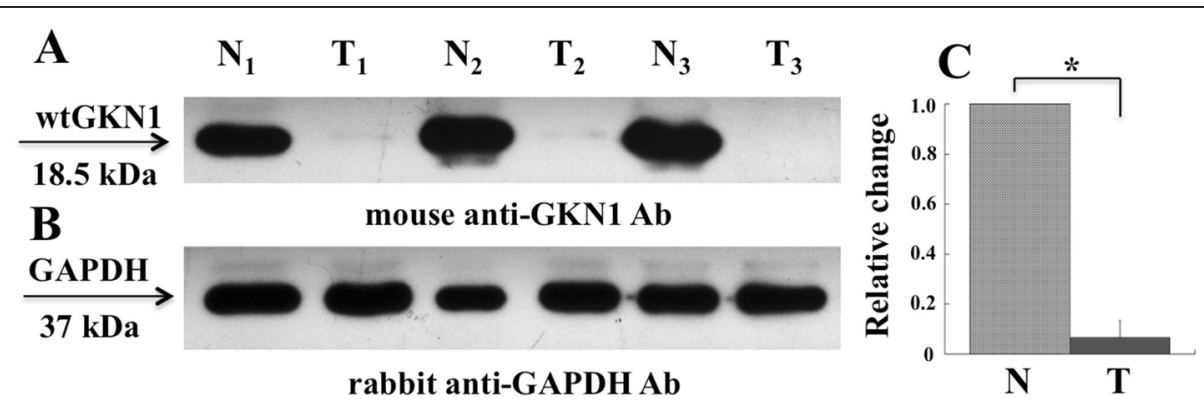

Fig. 3 Expression levels of GKN1 in human gastric tissues. a Representative Western blot of equal amounts of cell extracts $(20 \mu \mathrm{g})$ analyzed in paired non-tumoral $\left(N_{1}, N_{2}, N_{3}\right)$ and tumoral $\left(T_{1}, T_{2}, T_{3}\right)$ human gastric samples using mouse anti-GKN1 (a) and rabbit anti-GAPDH (b) antibodies (Ab). c qRT-PCR analysis. Total RNA was prepared from gastric tissues and analyzed by qRT-PCR for GKN1 mRNA level. Samples: N and T, nontumoral and tumoral gastric tissues, respectively. Data from three experiments are reported as mean values \pm SD. ${ }^{*} P<0.05$ 

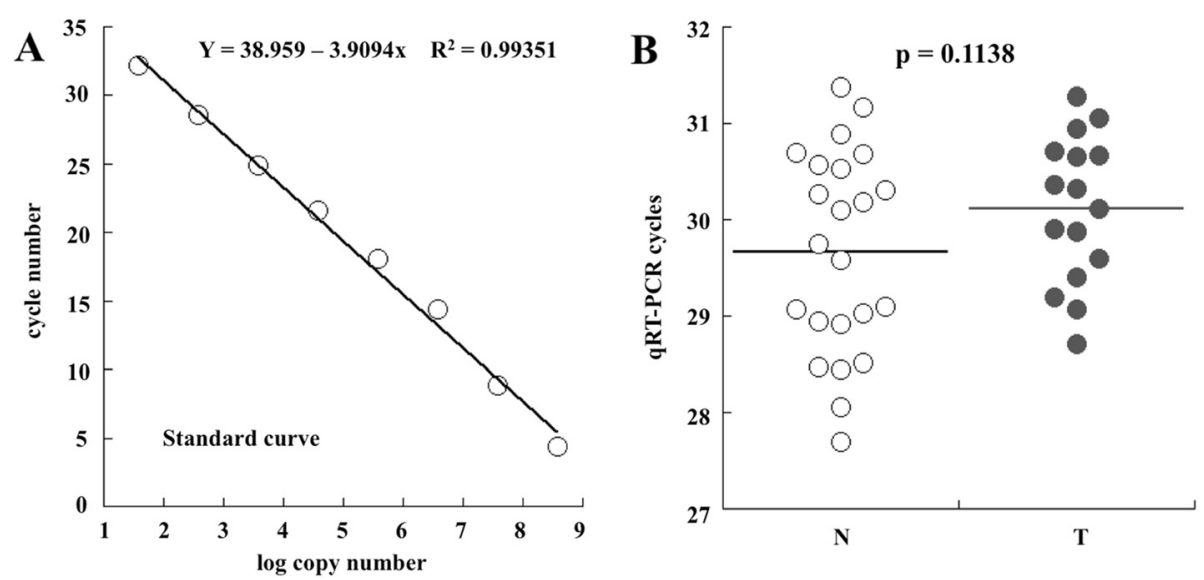

Fig. 4 qRT-PCR of GKN1 mRNA levels in human sera. a Standard calibration curve constructed using pCDNA3.1 vector containing the cDNA encoding human GKN1 (pCDNA3.1-flGKN1). $\mathbf{b}$ Statistical evaluation of the results of the qRT-PCR performed on human sera from a population of healthy individuals $(\mathrm{N})$ and from patients with gastric cancer $(\mathrm{T})$

healthy subjects as well as in that of patients with diagnosis of gastric cancer, when we analyzed by qRT-PCR these sera, we did not observe significant statistical differences among the two population. Therefore, we could not confirm our hypothesis that GKN1 mRNA could serve as non-invasive marker for GC.

\section{Methods}

\section{Population}

The study population comprised 16 patients with GC recruited at Hospital A. Cardarelli, Naples, Italy. All volunteers (23 individuals) were subjected to careful anamnesis and all those who had dyspeptic symptoms were excluded. Patients were interviewed regarding smoking habit, alcohol intake and chronic use of drugs and informed consent from each patient was obtained. Hospital Pathologist performed the macro dissection of tumor and non-tumor tissues of GC patients during surgery. Blood samples from these patients were collected before surgery and soon stored at $-20{ }^{\circ} \mathrm{C}$. Gastric cancer was classified according to Lauren criteria [20]. The study reported in the manuscript has been carried out in the frame of a research protocol entitled "Role of gastrokine 1 in gastric cancer" that has the approval from the Ethic Committee of the University of Naples Federico II (Comitato Etico Università Federico II). The assigned protocol number of the study was 34/15.

\section{Western blotting}

Proteins from cell extracts were analyzed by Western blotting using mouse anti-GKN1 monoclonal antibody, clone 2E5 (Abnova, Taipei, Taiwan) at a dilution of 1:500. Detection was performed using the enhanced chemiluminescence detection kit (SuperSignal West Pico) following manufacturer's instructions. All films were analyzed by using the Image J software. Western blot band intensity was measured with ImageJ 1.46r software.

\section{Serum samples for Western blotting and PCR analyses}

Serum samples from healthy or gastric cancer subjects were prepared immediately after blood samples withdrawn and stored at $-80{ }^{\circ} \mathrm{C}$. For Western blotting, $1 \mathrm{~mL}$ of serum was diluted 1:1 with $\mathrm{H}_{2} \mathrm{O}$ and centrifuged at 4,000 rpm in Centricon 30 (Millipore, Darmstadt, Germany) to separate higher size proteins. Filtered sample was then lyophilized overnight, re-suspended in $50 \mu \mathrm{L} \mathrm{H}_{2} \mathrm{O}$ and analyzed by Western blotting using mouse anti-GKN1 antibody, or by GKN1 ELISA Kit (Cloud-Clone Corp, Huston, USA), according to the manufacturer instruction.

Total RNA from $1 \mathrm{~mL}$ of serum sample was prepared using miRNeasy Serum/Plasma Kit (Qiagen). RNA concentration was measured using the NanoDrop 1000 spectrophotometer (Thermo Fisher Scientific). $1 \mu \mathrm{g}$ of total RNA was retro-transcribed with the iScript cDNA Synthesis Kit (Bio-Rad, Milan). $4 \mu$ of cDNA were amplified with 1 unit of Taq DNA Polymerase (Invitrogen) in the buffer provided by the manufacturer not containing $\mathrm{MgCl}_{2}$. Reactions were carried out in the PTC-0150 Mini-Cycler (Biorad) according to the following condition: first cycle of $5 \mathrm{~min}$ at $95{ }^{\circ} \mathrm{C}$ followed by 30 cycles $\left(30 \mathrm{~s}\right.$ at $95^{\circ} \mathrm{C}, 40 \mathrm{~s}$ at $58{ }^{\circ} \mathrm{C}, 30 \mathrm{~s}$ at $72{ }^{\circ} \mathrm{C}$ ) and $10 \mathrm{~min}$ at $72^{\circ} \mathrm{C}$. GAPDH was used as a control.

For semi-quantitative PCR, the following primers were designed: F1, cctctgtccactgctttcgt, R1, tggttgcagcaaagccattt; F2, cttcagggtaagggaccag, R2, cttgcctcttgcatctcctca; F3, ctttctagctcetgccetagc, R3, gttgcagcaaagccatttcc; F4, caacaatgctggaagt gggc, R4, tcccttaccetgaagttcttt.

For qRT-PCR, GKN1 cDNA was amplified using as primers F2-R2. qRT-PCR was performed with the SYBR 
Green PCR MasterMix (Applied Biosystems) under the following conditions: $10 \mathrm{~min}$ at $95{ }^{\circ} \mathrm{C}$, followed by $40 \mathrm{cy}$ cles $\left(15 \mathrm{~s}\right.$ at $95{ }^{\circ} \mathrm{C}$ and $1 \mathrm{~min}$ at $\left.60{ }^{\circ} \mathrm{C}\right)$. Each reaction was performed in duplicate. We used the $2^{-\Delta \Delta C T}$ method to calculate the relative expression levels [22]. Results on serum samples were evaluated by absolute quantitation using a standard curve constructed using dilution of plasmid pCDNA3.1 containing GKN1 cDNA (pCDNA3.1-flGKN1) [34].

qRT-PCR and Western blotting from gastric tissues. Total RNA was extracted from non-tumoral and tumoral human tissues using TRIzol reagent solution (Invitrogen) according to the manufacturer's protocol. GKN1 cDNA was amplified by qRT-PCR using F3-R3 primers, as above reported. Protein extracts from gastric tissues were prepared and analyzed by Western blotting as described [8].

\section{Statistical analyses}

Statistical analyses were performed by two-tailed unpaired or paired Student's $t$-test using KaleidaGraph 4.1.1 software. Data were reported as means \pm standard deviation (SD). The significance was accepted at the level of $p<0.05$.

\section{Abbreviations}

GAPDH, glyceraldehyde-3-phosphate dehydrogenase; GC, gastric cancer; GKN1, gastrokine 1; HAS, human serum albumin

\section{Acknowledgments}

This work was supported by funds from Programmi di Ricerca Scientifica di Rilevante Interesse Nazionale (2012CK5RPF_004), PON Ricerca e Competitività 2007-2013 (PON01_02782) and POR Campania FSE 2007-2013, Project CRĖME.

\section{Authors' contributions}

CSDS, W and GM carried out all experiment; take care of sample collection and RNA preparation. FA analyzed the data and wrote the manuscript. AF performed GRT-PCR analyses and statistical evaluation. MDP take care of patient recruitment and informed consent, ER supervised collection of the gastric cancer samples and clinical data. PA provided critical revision of the results. All authors read and approved the final manuscript.

\section{Competing interests}

The authors declare that they have no competing interests.

\section{Author details}

'Department of Molecular Medicine and Medical Biotechnology, University of Naples Federico II, Via S. Pansini 5, I-8031 Naples, Italy. ${ }^{2}$ Hospital A. Cardarelli, Nasples, Italy. ${ }^{3}$ CEINGE, Advanced Biotechnology scarl, Naples, Italy.

Received: 11 March 2016 Accepted: 14 June 2016

Published online: 25 July 2016

\section{References}

1. Anker $P$, Mulcahy $H$, Chen $X Q$, et al. Detection of circulating tumour DNA in the blood (plasma/serum) of cancer patients. Cancer Metastasis Rev. 1999;18:65-73.

2. Bornschein J, Rokkas T, Selgrad M, Malfertheiner P. Gastric cancer: clinical aspects, epidemiology and molecular background. Helicobacter. 2011;1:45-52.

3. Bunn Jr PJ. Early detection of lung cancer using serum RNA or DNA markers: ready for "prime time" or for validation? J Clin Oncol. 2003;21:3891-3.

4. Correa P. Helicobacter pylori and gastric carcinogenesis. Am J Surg Pathol. 1995;SS43:37.
5. Correa P. Human gastric carcinogenesis: a multistep and multifactorial process-First American Cancer Society Award Lecture on Cancer Epidemiology and Prevention. Cancer Res. 1992;52:6735-40.

6. Cunningham SC, Kamangar F, Kim MP, Hammoud S, Haque R, Maitra A, Montgomery E, Heitmiller RE, Choti MA, Lillemoe KD, Cameron JL, Yeo CJ, Schulick RD. Survival after gastric adenocarcinoma resection: eighteen-year experience at a single institution. J Gastrointest Surg. 2005;9:718-25.

7. Dean JD, Goodwin PH, Hsiang T. Comparison of relative RT-PCR and Northern blot analyses to measure expression of $\beta$-1,3-glucanase in nicotiana benthamiana infected with colltotrichum destructivum. Plant Mol Biol Rep. 2002;20:347-56.

8. Di Stadio CS, Altieri F, Miselli M, Elce A, Severino V, Chambery A, Quagliariello V, Villano V, de Dominicis G, Rippa E, Arcari P. AMP18 interacts with the anion exchanger SLC26A3 and enhances its expression in gastric cancer cells. Biochimie. 2016;121:151-60.

9. Du JJ, Dou KF, Peng SY, Wang WZ, Wang ZH, Xiao HS, Guan WX, Liu YB, Gao ZQ. Down-regulated full-length novel gene GDDR and its effect on gastric cancer. Zhonghua Yi Xue Za Zhi. 2003;83:1166-8.

10. El-Hefnawy T, Raja S, Kelly L, Bigbee WL, Kirkwood JM, Luketich JD, Godfrey TE. Characterization of amplifiable, circulating RNA in plasma and its potential as a tool for cancer diagnostics. Clin Chem. 2004:50:564-73.

11. Faycal J, Bessaguet C, Nousbaum JB, Cauvin JM, Cholet F, Bideau K, Robaszkiewicz M, Gouérou H. Epidemiology and long term survival of gastric carcinoma in the French district of Finistere between 1984 and 1995. Gastroenterol Clin Biol. 2005;29:23-32.

12. Fugazzola L, Mihalich A, Persani L, Cerutti N, Reina M, Bonomi M, Ponti E, Mannavola D, Giammona E, Vannucchi G, di Blasio AM, Beck-Peccoz P. Highly sensitive serum thyroglobulin and circulating thyroglobulin mRNA evaluations in the management of patients with differentiated thyroid cancer in apparent remission. J Clin Endocrinol Metab. 2002:87:3201-8.

13. Guo XY, Dong L, Qin B, Jiang J, Shi AM. Decreased expression of gastrokine 1 in gastric mucosa of gastric cancer patients. World J Gastroenterol. 2014;20:16702-6.

14. Iguchi H, Kosaka N, Ochiya T. Secretory microRNAs as a versatile communication tool. Commun Integr Biol. 2010;3:478-81.

15. Juusola J, Ballantyne J. Messenger RNA profiling: a prototype method to supplant conventional methods for body fluid identification. Forensic Sci Int. 2003;135:85-96.

16. Kamangar F, Dores GM, Anderson WF. Patterns of cancer incidence, mortality, and prevalence across five continents: defining priorities to reduce cancer disparities in different geographic regions of the world. J Clin Oncol. 2006;24:2137-50.

17. Kopreski MS, Benko FA, Gocke CD. Circulating RNA as a tumor marker: detection of 5 T4 mRNA in breast and lung cancer patient serum. Ann N Y Acad Sci. 2001;945:172-8.

18. Kopreski MS, Benko FA, Kwak LW, Gocke CD. Detection of tumor messenger RNA in the serum of patients with malignant melanoma. Clin Cancer Res. 1999:5:1961-5.

19. Lacy ER, Morris GP, Cohen MM. Rapid repair of the surface epithelium in human gastric mucosa after acute superficial injury. J Clin Gastroenterol. 1993;17:S125-35.

20. Lauren P. The two histological main types of gastric carcinoma: diffuse and so-called intestinaltype carcinoma. An attempt at a histo-clinical classification. Acta Pathol Microbiol Scand. 1965;64:31-49.

21. Li Y, Elashoff D, Oh M, Sinha U, St John MAR, Zhou X, Abemayor E, Wong DT. Serum circulating human mRNA profiling and its utility for oral cancer detection. J Clin. 2006;24:1754-60.

22. Livak KJ, Schmittgen TD. Analysis of relative gene expression data using real-time quantitative PCR and the 2(-Delta Delta C(T)) Method. Methods. 2001;25:402-8.

23. Martin TE, Powell CT, Wang Z, Bhattacharyya S, Walsh-Reitz MM, Agarwal K, Toback FG. A novel mitogenic protein that is highly expressed in cells of the gastric antrum mucosa. Am J Physiol Gastrointest Liver Physiol. 2003;285:G332-43.

24. Menheniott TR, Kurklu B, Giraud AS. Gastrokines: stomach-specific proteins with putative homeostatic and tumor suppressor roles. Am J Physiol Gastrointest Liver Physiol. 2013;304:G109-21.

25. Menheniott TR, O'Connor L, Chionh YT, Däbritz J, Scurr M, Rollo BR, Ng GZ Jacobs S, Catubig A, Kurklu B, Mercer S, Minamoto T, Ong DE, Ferrero RL, Fox JG, Wang TC, Sutton P, Judd LM, Giraud AS. Loss of gastrokine-2 drives premalignant gastric inflammation and tumor progression. J Clin Invest. 2016;126:1383-400. 
26. Menheniott TR, Peterson AJ, O'connor L, Lee KS, Kalantzis A, Kondova I, Bontrop RE, Bell KM, Giraud AS.. A novel gastrokine in mammals marks gastric atrophy and shows evidence of adaptive gene loss in human. Gastroenterology. 2010;138:1823-35.

27. Miura N, Hasegawa J, Shiota G. Serum messenger RNA as a biomarker and its clinical usefulness in malignancies. Oncology. 2008;2:5.

28. Nardone G, Martin G, Rocco A, Rippa E, La Monica G, Caruso F, Arcari P. Molecular expression of gastrokine 1 in normal mucosa and in helicobacter pylori-related preneoplastic and neoplastic gastric lesions. Cancer Biol Ther. 2008;7:1890-5

29. Oien KA, McGregor F, Butler S, Ferrier RK, Downie I, Bryce S, Burns S, Nicol W, Keith WN. Gastrokine 1 is abundantly and specifically expressed in superficial gastric epithelium, down-regulated in gastric carcinoma, and shows high evolutionary conservation. J Pathol. 2004;203:789-97.

30. Parkin DM, Whelan SL, Ferlay J, Teppo L, Thomas DB. Cancer incidence in five continents, Vol VIII. Lyon, France, IARC Scientific Publications No. 155, 2002.

31. Rieger-Christ KM, Mourtzinos A, Lee PJ, Zagha RM, Cain J, Silverman M, Libertino JA, Summerhayes IC. Identification of fibroblast growth factor receptor 3 mutations in urine sediment DNA samples complements cytology in bladder tumor detection. Cancer. 2003;98:737-44.

32. Ries LAG, Eisner MP, Kosary CL, Hankey BF, Miller BA, Clegg L, Mariotto A, Feuer EJ, Edwards BK (eds). SEER Cancer Statistics Review. Bethesda, MD: National Cancer Institute; 1975-2002. http://seer.cancer.gov/csr/1975_2002/ sections.html.

33. Rippa E, Altieri F, Di Stadio CS, Miselli G, Lamberti A, Federico A, Quagliariello V, Papale F, Guerra G, Arcari P. Ectopic expression of gastrokine 1 in gastric cancer cells up-regulates tight and adherens junction proteins network. Pathol Res Pract. 2015;211:577-83.

34. Rippa E, La Monica G, Allocca R, Romano MF, De Palma M, Arcari P. Overexpression of gastrokine 1 in gastric cancer cells induces fas-mediated apoptosis. J Cell Physiol. 2011;226:2571-8.

35. Roukos DH, Kappas AM. Perspectives in the treatment of gastric cancer. Nat Clin Pract Oncol. 2005;2:98-107.

36. Toback FG, Walsh-Reitz MM, Musch MW, Chang EB, Del Valle J, Ren H, Huang E, Martin TE. Peptide fragments of AMP-18, a novel secreted gastric antrum mucosal protein, are mitogenic and motogenic. Am J Physiol Gastroint Liver Physiol. 2003;285:G344-53.

37. Tsubono Y, Hisamichi S. Screening for gas- tric cancer in Japan. Gastric Cancer. 2000;3:9-18.

38. Tsui NBY, Ng EK, Lo YM. Stability of Endogenous and Added RNA in Blood Specimens, Serum, and Plasma. Clin Chem. 2002;48:1647-53.

39. Wong L, Lueth M, Li XN, Lau CC, Vogel H. Detection of mitochondrial DNA mutations in the tumor and cerebrospinal fluid of medulloblastoma patients. Cancer Res. 2003;63:3866-71.

40. Wong SC, Lo SF, Cheung MT, Ng KO, Tse CW, Lai BS, Lee KC, Lo YM. Quantification of plasma beta-catenin mRNA in colorectal cancer and adenoma patients. Clin Cancer Res. 2004;10:1613-7.

41. Xu MD, Qi P, Du X. Long non-coding RNAs in colorectal cancer: implications for pathogenesis and clinical application. Mod Pathol. 2014;27:1310-20.

42. Manzour H.Yoon JH, Choi YJ, Choi WS, Ashktorab H, Smoot DT, Nam SW, Lee JY, Park WS. GKN1-miR-185-DNMT1 axis suppresses gastric carcinogenesis through regulation of epigenetic alteration and cell cycle. Clin Cancer Res. 2013;19:4599-610.

43. Zamanian-Azodi M, Rezaei-Tavirani M, Hasanzadeh H, Rahmati Rad SR, Dalilan S, Gilanchi S, Manzour H. Introducing biomarker panel in esophageal, gastric, and colon cancers; a proteomic approach. Gastroenterol Hepatol Bed Bench. 2015;8:6-18.

\section{Submit your next manuscript to BioMed Central and we will help you at every step:}

- We accept pre-submission inquiries

- Our selector tool helps you to find the most relevant journal

- We provide round the clock customer support

- Convenient online submission

- Thorough peer review

- Inclusion in PubMed and all major indexing services

- Maximum visibility for your research

Submit your manuscript at www.biomedcentral.com/submit
Biomed Central 